\title{
Dynamics of Microbial Indicators in Waste Water
}

\author{
Vlad STOIAN, Roxana VIDICAN*, Ioan ROTAR, Florin PĂCURAR \\ Faculty of Agriculture. Department of Plant Culture. University of Agricultural Sciences and Veterinary \\ Medicine Cluj-Napoca, Calea Manastur no. 3-5, 400372 Cluj-Napoca, Romania \\ *corresponding author: roxana.vidican@usamvcluj.ro
}

Bulletin USAMV series Agriculture 74(2)/2017

Print ISSN 1843-5246; Electronic ISSN 1843-5386

DOI 10.15835/buasvmcn-agr: 0036

\begin{abstract}
Water ecosystems are constantly under the pressure of a high number of biotic and abiotic factors, and their action leads to the occurrence of fluctuations in species and populations. The specific response of organisms to external pressures leads to the reorganization of ecosystems, with qualitative and quantitative changes. The aim is to identify the microbial groups with the highest potential in the waste waters. Data were collected during 2015-16 in Bistrita. Identifying the bioindicators quality of microorganisms and their importance in ecosystems was done by comparing them with international databases. The use of microorganisms as bioindicators involves knowing the requirements for one or more environmental variables. The concept refers to the ability of microorganisms to accumulate pollutants. Flagellates are tolerant to acidity and react quickly and with sensitivity to environmental stress by inhibiting their movement. The multiplication of flagellates and filamentous bacteria is manifested through water disturbance and foam production.
\end{abstract}

Keywords: waste water, bioindicators, ciliates.

\section{INTRODUCTION}

Water as well as air is an environmental factor indispensable to life, it is always found where life exists and forms the most widespread substance on earth. The fight against water pollution is achieved through measures aimed primarily at preventing water pollution. For many industrial branches, for animal husbandry and various social activities, the most effective way to combat and limit pollution is to purify wastewater before discharge. In this operation, the waste water is subjected to successive treatments, whereby the content of pollutants is diminished so that after dilution with the waters of the rivers they reach, they register the lowest concentrations (Agrawal and Gopal, 2013). The treatments that apply include process-based technologies and natural phenomena: physical, chemical and biological, applied differently to different categories of wastewater (Mara and Horan, 2003). Different techniques and working methods vary depending on the composition of the wastewater.
Surface waters, rivers, lakes and maritime waters have adhering flora and fauna with a diversity and richness of high species (Grosberg et al., 2012). In addition to typical water species, micro-organisms from terrestrial ecosystems with contamination potential also appear (Jamieson et al, 2002). Underground waters, due to their oligotrophic character (nutrient deficiency), typically have a poor microflora, represented by a small number of species, with almost complete lack of plants or higher animals (Pipkin et al, 2013). The development of biota (flora and fauna) in surface waters is governed by a variety of environmental conditions that determine species selection as well as the physiological performance of individual organisms (Morgan and Maitland, 1997). Primary production of organic matter, in the form of phytoplankton and macrophytes, is more intense in lakes and reservoirs and is usually more limited in rivers (Fellman et al., 2014; Shen et al., 2012). Degradation of organic substances and associated bacterial production 
may be a long-term process that may be important in groundwater and deep-sea water not exposed directly to sunlight (Chapman, 1996; Findlay and Sinsabaugh, 2003).

Water quality is most affected by man-made discharges of wastewater. Quality indices for natural waters are set by a series of regulations (Howarth, 2005; Jarvie and Jenkins, 2014; Verhoeven et al., 2006). The Environmental Law mentions that the protection of surface and underground water and aquatic ecosystems aims at maintaining and improving their natural quality and productivity in order to avoid adverse effects on the environment, human health and material goods. Water pollution is the direct or indirect modification of the composition of normal water as a result of human activity to such an extent that it adversely affects the characteristics of the water, preventing its use in the natural state (Camargo and Alonso, 2006; Lu et al., 2015; Wurzel, 2002).

\section{MATERIALS AND METHODS}

In Romania, the Integrated Water Monitoring System has an informational structure and a hierarchical structure. Local water management authorities (Water Management Systems) are responsible for obtaining, collecting and transmitting information to the water management basin authorities (Water Directorates) and, further, to the national water management authority (the National Authority for Water Management) and to the central water management authority (Ministry of Environment). In the case of water treatment, active sludge is taken from the aeration pools and the presence of groups of microorganisms (unicellular organisms, pluricelular organisms, filamentous bacteria or other components) are evaluated.

Laboratory analyzes are performed within 2-3 days to avoid major changes. The purpose is to indicate the capacity of the sedimentation sludge and to prevent the sludge from getting into the secondary decanters because if it remains in suspension there is the danger of getting into running water. Also, the purpose of the analyzes is to have an evidence of the biological flow and to keep the number of filamentous bacteria in optimal parameters. From the purification point of view, ciliates are more desirable than bacteria, because they are best able to intervene in biological treatment.
The purpose of this paper is to analyze the dynamics of the microbial groups in the active sludge from the Bistrita Wastewater Treatment Plant during the years 2015-2016. The main groups were: free (CiFree) and fixed ciliate (CiFix), flagellates (Flag), amoebas (Am) and filamentous bacteria (BacFil). Along with these, other genera and groups have been analyzed (Aspidisca, Epistylis, Microthrix, Podophrya, Sphaerotilus, Tokophyra, Votricella). Data analysis was performed with Statistica 10 (StatSoft Inc, 2011) for ANOVA, Fisher-LSD and histograms.

\section{RESULTS AND DISCUSSIONS}

During the period 2015-2016, the presence of fixed and loose ciliates, flagellates, filamentous bacteria, amoebae, worms or other components such as rotifers have been noted. Ciliates are desirable and efficient because they interfere with the decomposition process of wastewater. If interfering substances occur, there is a multiplication of flagellates and filamentous bacteria that produce a slurry of purified water. The filamentous bacteria produce foam and form as a blanket, a fabric on the surface of the water, and the sludge becomes easier, with the bacteria reaching the river mud. If there are detergents, fats, petroleum substances, bacteria multiply and the number of ciliates.

The study is based on a total of 105 samples (Tab. 1), with the largest amounts of abundance of microorganisms being observed in the groups of filamentous bacteria (315) and free ciliate (212). The variance found in the entire study is between 0.52 and 2.20 , the amoebas having the strongest variations from one month to the next (2.20). The standard deviation remains below 1.48 (amoebas) and above 0.72 (fixed ciliate). The largest recorded media are the free ciliate and filamentous bacteria (2.02 and 3.00) which demonstrate the constant presence of these microbial groups. Variance analysis indicates a high potential for changing the abundance / dominance of microbial groups in water due to climate, with very significant differences between the periods studied (Tab. 1). Amyles amoebas vary strongly from month to month $(F=48.276)$, while filamentous bacteria retain their consistency throughout the year $(F=5.090)$. Free and fixed cilindres, or flags, have the same variation potential throughout the year. 
Tab. 1. Descriptive statistics of microbial samples

\begin{tabular}{lccccccc}
\hline & Valid case & Mean & Sum & Varince & Std. dev. & F & P \\
\hline CiFree & 105 & 2.02 & 212 & 1.17 & 1.08 & 11.615 & $\mathrm{p}<0.001$ \\
\hline CiFix & 105 & 1.57 & 165 & 0.52 & 0.72 & 12.353 & $\mathrm{p}<0.001$ \\
\hline Flag & 105 & 0.48 & 50 & 0.91 & 0.95 & 12.032 & $\mathrm{p}<0.001$ \\
\hline Am & 105 & 1.23 & 129 & 2.20 & 1.48 & 48.276 & $\mathrm{p}<0.001$ \\
\hline BacFil & 105 & 3.00 & 315 & 1.40 & 1.18 & 5.090 & $\mathrm{p}<0.001$ \\
\hline Other groups & 105 & 0.45 & 47 & 0.85 & 0.92 & 2.455 & 0.015 \\
\hline
\end{tabular}

Note: Significant variations (ANOVA test $-F, p<0.05 / p<0.01 / p<0.001$ ).

Tab. 2. Dynamics of free ciliate during 2015-2016

\begin{tabular}{ccccccccccc}
\hline & Jan & Apr & May & Jun & Jul & Aug & Sep & Oct & Nov & Dec \\
\hline Mean & 3.000 & 2.667 & 2.400 & 1.000 & 1.000 & 0.500 & 2.200 & 1.667 & 1.800 & 3.000 \\
\hline Jan & & 0.396 & 0.115 & $\mathrm{p}<0.001$ & $\mathrm{p}<0.001$ & $\mathrm{p}<0.001$ & 0.037 & 0.002 & 0.002 & 1.000 \\
\hline Apr & 0.396 & & 0.381 & $\mathrm{p}<0.001$ & 0.001 & $\mathrm{p}<0.001$ & 0.127 & 0.005 & 0.005 & 0.299 \\
\hline May & 0.115 & 0.381 & & $\mathrm{p}<0.001$ & 0.006 & $\mathrm{p}<0.001$ & 0.485 & 0.028 & 0.038 & 0.050 \\
\hline Jun & $\mathrm{p}<0.001$ & $\mathrm{p}<0.001$ & $\mathrm{p}<0.001$ & & 1.000 & 0.204 & 0.002 & 0.109 & 0.037 & $\mathrm{p}<0.001$ \\
\hline Jul & $\mathrm{p}<0.001$ & 0.001 & 0.006 & 1.000 & & 0.324 & 0.017 & 0.204 & 0.109 & $\mathrm{p}<0.001$ \\
\hline Aug & $\mathrm{p}<0.001$ & $\mathrm{p}<0.001$ & $\mathrm{p}<0.001$ & 0.204 & 0.324 & & $\mathrm{p}<0.001$ & 0.001 & $\mathrm{p}<0.001$ & $\mathrm{p}<0.001$ \\
\hline Sep & 0.037 & 0.127 & 0.485 & 0.002 & 0.017 & $\mathrm{p}<0.001$ & & 0.109 & 0.164 & 0.010 \\
\hline Oct & 0.002 & 0.005 & 0.028 & 0.109 & 0.204 & 0.001 & 0.109 & & 0.687 & $\mathrm{p}<0.001$ \\
\hline Nov & 0.002 & 0.005 & 0.038 & 0.037 & 0.109 & $\mathrm{p}<0.001$ & 0.164 & 0.687 & & $\mathrm{p}<0.001$ \\
\hline Dec & 1.000 & 0.299 & 0.050 & $\mathrm{p}<0.001$ & $\mathrm{p}<0.001$ & $\mathrm{p}<0.001$ & 0.010 & $\mathrm{p}<0.001$ & $\mathrm{p}<0.001$ & \\
\hline
\end{tabular}

Note: Significant differences $(p<0.05 / p<0.01 / p<0.001)$.

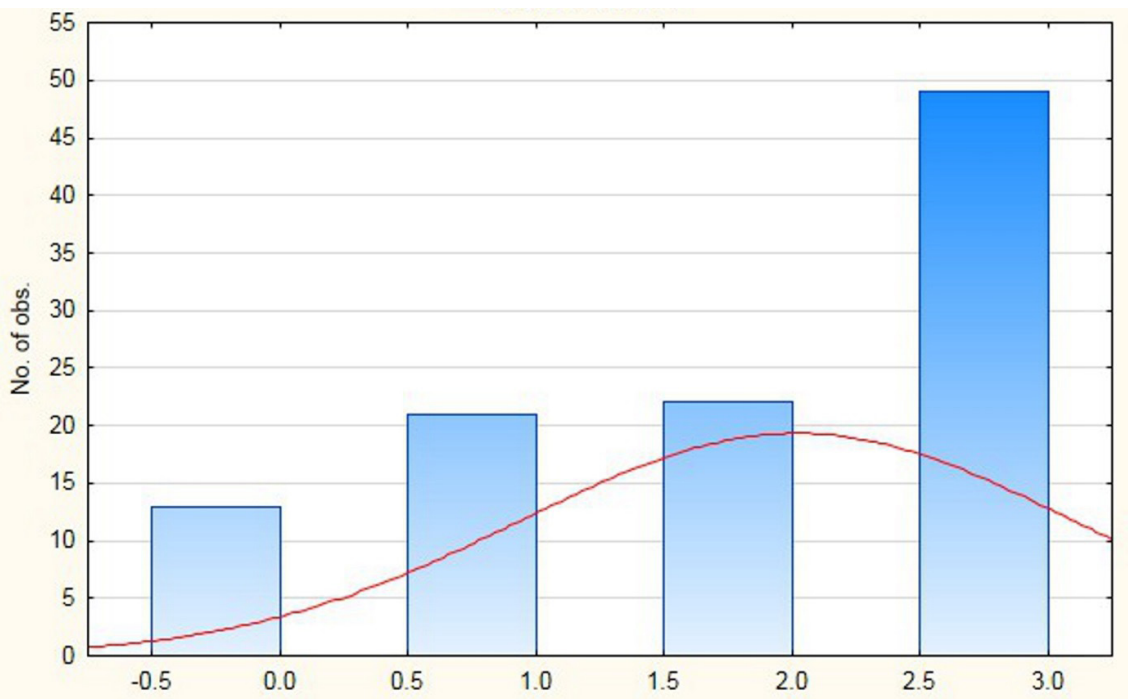

Fig. 1. Free ciliates growth curve during 2015-2016 
Most free ciliates are present in DecemberJanuary (3.00), with significant differences compared to other periods of the year (Tab. 2). At the opposite end, there are summer months with a low abundance of these microorganisms (0.5-1.0), which indicates the lower conservation potential in the aquatic community due to high temperatures. The spring and autumn months determine an average-abundant presence of free ciliates, but only for short periods of time and with wide fluctuations. Free ciliates have a relatively normal distribution throughout the study, most samples, about 50, having a mean abundance to high (2.5-3.0, Fig. 1).

Fixed ciliates (Tab. 3) have lower abundance values than those observed at free ciliates. Values are higher in winter and high rainfall, but are not nearly complete in the summer months. The differences between the recorded values are very significant between the cold and the warm and the insignificant during the same season. The normal curve of the fixed ciliate indicates an average presence of abundance of fixed ciliate,

Tab. 3. Dynamics of fixed ciliates in the period 2015-2016

\begin{tabular}{ccccccccccc}
\hline & Jan & Apr & May & Jun & Jul & Aug & Sep & Oct & Nov & Dec \\
\hline Mean & 2.000 & 1.833 & 2.000 & 0.500 & 0.000 & 1.000 & 1.933 & 1.000 & 1.800 & 1.750 \\
\hline Jan & & 0.515 & 1.000 & $\mathrm{p}<0.001$ & $\mathrm{p}<0.001$ & $\mathrm{p}<0.001$ & 0.787 & $\mathrm{p}<0.001$ & 0.419 & 0.330 \\
\hline Apr & 0.515 & & 0.401 & $\mathrm{p}<0.001$ & $\mathrm{p}<0.001$ & $\mathrm{p}<0.001$ & 0.614 & $\mathrm{p}<0.001$ & 0.866 & 0.690 \\
\hline May & 1.000 & 0.401 & & $\mathrm{p}<0.001$ & $\mathrm{p}<0.001$ & $\mathrm{p}<0.001$ & 0.721 & $\mathrm{p}<0.001$ & 0.286 & 0.209 \\
\hline Jun & $\mathrm{p}<0.001$ & $\mathrm{p}<0.001$ & $\mathrm{p}<0.001$ & & 0.169 & 0.053 & $\mathrm{p}<0.001$ & 0.066 & $\mathrm{p}<0.001$ & $\mathrm{p}<0.001$ \\
\hline Jul & $\mathrm{p}<0.001$ & $\mathrm{p}<0.001$ & $\mathrm{p}<0.001$ & 0.169 & & 0.003 & $\mathrm{p}<0.001$ & 0.004 & $\mathrm{p}<0.001$ & $\mathrm{p}<0.001$ \\
\hline Aug & $\mathrm{p}<0.001$ & $\mathrm{p}<0.001$ & $\mathrm{p}<0.001$ & 0.053 & 0.003 & & $\mathrm{p}<0.001$ & 1.000 & $\mathrm{p}<0.001$ & 0.001 \\
\hline Sep & 0.787 & 0.614 & 0.721 & $\mathrm{p}<0.001$ & $\mathrm{p}<0.001$ & $\mathrm{p}<0.001$ & & $\mathrm{p}<0.001$ & 0.476 & 0.356 \\
\hline Oct & $\mathrm{p}<0.001$ & $\mathrm{p}<0.001$ & $\mathrm{p}<0.001$ & 0.066 & 0.004 & 1.000 & $\mathrm{p}<0.001$ & & $\mathrm{p}<0.001$ & 0.001 \\
\hline Nov & 0.419 & 0.866 & 0.286 & $\mathrm{p}<0.001$ & $\mathrm{p}<0.001$ & $\mathrm{p}<0.001$ & 0.476 & $\mathrm{p}<0.001$ & & 0.801 \\
\hline Dec & 0.330 & 0.690 & 0.209 & $\mathrm{p}<0.001$ & $\mathrm{p}<0.001$ & 0.001 & 0.356 & 0.001 & 0.801 & \\
\hline
\end{tabular}

Note: Significant differences $(p<0.05 / p<0.01 / p<0.001)$.

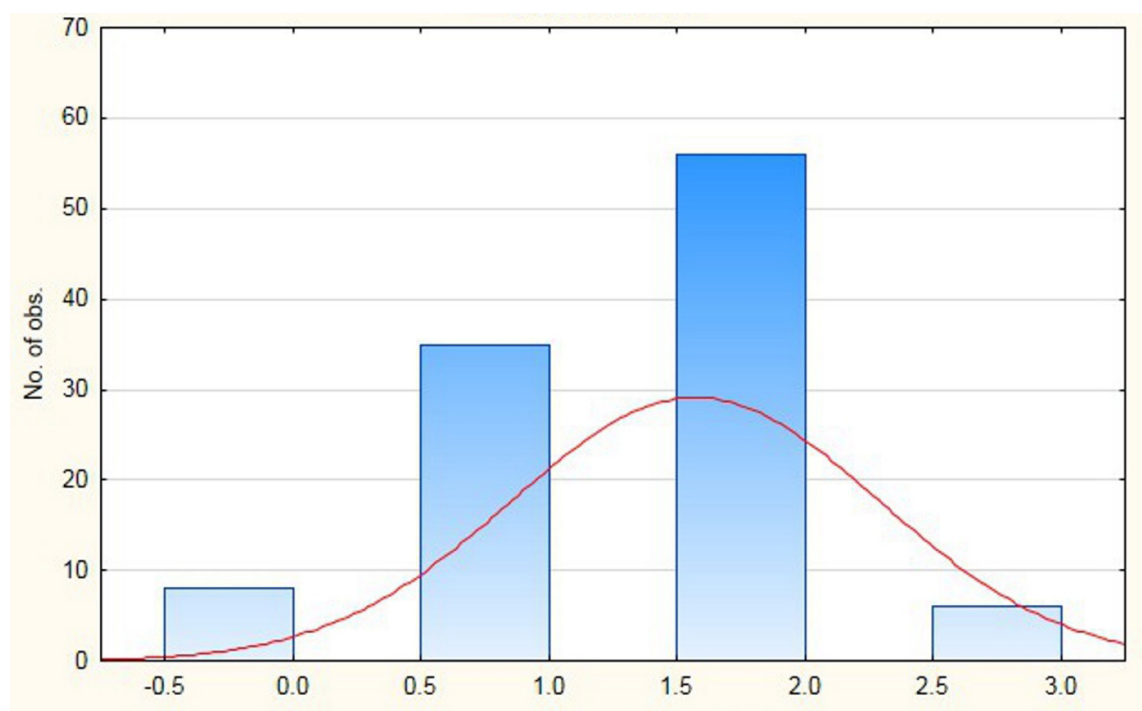

Fig. 2. Fixed ciliates growth curve during 2015-2016 
most samples being located in the abundance area of 1.5-2.0 (Fig. 2). The observed distribution indicates a nominal development of these microbial groups throughout the year and the potential for forecasting water quality depreciation.

Flagellates are present intermittently throughout the year (Tab. 4). Maximum abundance was observed in June $(2,5)$, while in August this parameter reached the value of 1,5. The differences between these months and the rest of the seasons are significant.
Flagellates also appear in the microbial community, sporadically, in the cold season, November to December, respectively in April, but with a low abundance and no significant seasons between seasons. The distribution of flagellates throughout the year is induced by changes in the nutrient support, most samples lacking this type of microorganisms, while the normal distribution curve indicates a low abundance potential over the whole year (Fig. 3).

Tab. 4. Dynamics of flagellates during 2015-2016

\begin{tabular}{ccccccccccc}
\hline & Jan & Apr & May & Jun & Jul & Aug & Sep & Oct & Nov & Dec \\
\hline Mean & 0.000 & 0.167 & 0.000 & 2.500 & 0.000 & 1.500 & 0.000 & 0.000 & 0.400 & 0.750 \\
\hline Jan & & 0.625 & 1.000 & $\mathrm{p}<0.001$ & 1.000 & $\mathrm{p}<0.001$ & 1.000 & 1.000 & 0.227 & 0.030 \\
\hline Apr & 0.625 & & 0.529 & $\mathrm{p}<0.001$ & 0.705 & $\mathrm{p}<0.001$ & 0.529 & 0.580 & 0.378 & 0.038 \\
\hline May & 1.000 & 0.529 & & $\mathrm{p}<0.001$ & 1.000 & $\mathrm{p}<0.001$ & 1.000 & 1.000 & 0.111 & 0.005 \\
\hline Jun & $\mathrm{p}<0.001$ & $\mathrm{p}<0.001$ & $\mathrm{p}<0.001$ & & $\mathrm{p}<0.001$ & 0.004 & $\mathrm{p}<0.001$ & $\mathrm{p}<0.001$ & $\mathrm{p}<0.001$ & $\mathrm{p}<0.001$ \\
\hline Jul & 1.000 & 0.705 & 1.000 & $\mathrm{p}<0.001$ & & 0.001 & 1.000 & 1.000 & 0.355 & 0.091 \\
\hline Aug & $\mathrm{p}<0.001$ & $\mathrm{p}<0.001$ & $\mathrm{p}<0.001$ & 0.004 & 0.001 & & $\mathrm{p}<0.001$ & $\mathrm{p}<0.001$ & $\mathrm{p}<0.001$ & 0.008 \\
\hline Sep & 1.000 & 0.529 & 1.000 & $\mathrm{p}<0.001$ & 1.000 & $\mathrm{p}<0.001$ & & 1.000 & 0.111 & 0.005 \\
\hline Oct & 1.000 & 0.580 & 1.000 & $\mathrm{p}<0.001$ & 1.000 & $\mathrm{p}<0.001$ & 1.000 & & 0.167 & 0.014 \\
\hline Nov & 0.227 & 0.378 & 0.111 & $\mathrm{p}<0.001$ & 0.355 & $\mathrm{p}<0.001$ & 0.111 & 0.167 & & 0.187 \\
\hline Dec & 0.030 & 0.038 & 0.005 & $\mathrm{p}<0.001$ & 0.091 & 0.008 & 0.005 & 0.014 & 0.187 & \\
\hline
\end{tabular}

Note: Significant differences $(p<0.05 / p<0.01 / p<0.001)$.

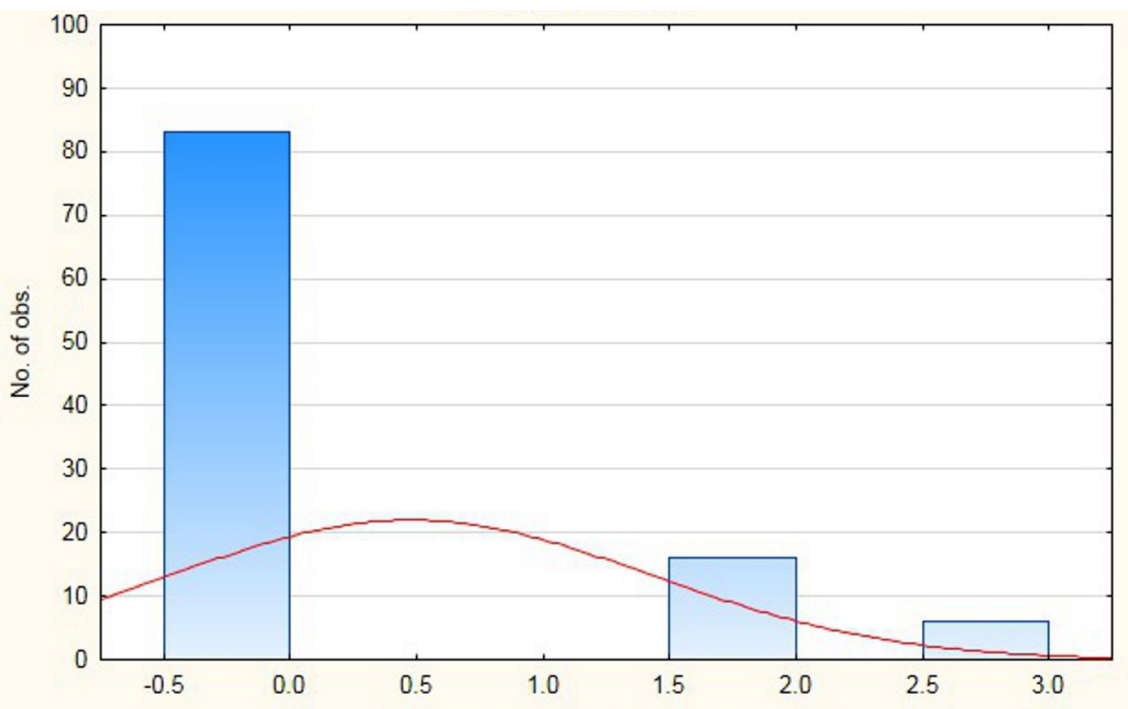

Fig. 3. Flagellates growth curve during 2015-2016 
Amoebas represent a microbial group with the highest variation from one month to another and from season to season (Tab. 5). The presence in the aquatic community is high since July (3.0), reaching a peak in August (3.5) and decreasing steadily during September-November, then disappearing as a group in December. The phenomenon is based on the accumulation of organic matter due to the activity of the other microbial groups during January-June and the use of this resource to exhaustion. Differences observed between seasons are very significant, but at seasonal level they are insignificant. Amoebas distribution is relatively close to normal development curves (Fig. 4), but there are periods with a strong growth of these microorganisms, with abundance higher than the potential of the ecosystem and periods when this group has no activity.

The filamentous bacteria dominate the microbial community especially in the warm

Tab. 5. Dynamics of amoebas in the period 2015-2016

\begin{tabular}{ccccccccccc}
\hline & Jan & Apr & May & Jun & Jul & Aug & Sep & Oct & Nov & Dec \\
\hline Mean & 0.000 & 0.000 & 0.000 & 0.000 & 3.000 & 3.500 & 2.400 & 2.667 & 1.200 & 0.000 \\
\hline Jan & & 1.000 & 1.000 & 1.000 & $\mathrm{p}<0.001$ & $\mathrm{p}<0.001$ & $\mathrm{p}<0.001$ & $\mathrm{p}<0.001$ & $\mathrm{p}<0.001$ & 1.000 \\
\hline Apr & 1.000 & & 1.000 & 1.000 & $\mathrm{p}<0.001$ & $\mathrm{p}<0.001$ & $\mathrm{p}<0.001$ & $\mathrm{p}<0.001$ & $\mathrm{p}<0.001$ & 1.000 \\
\hline May & 1.000 & 1.000 & & 1.000 & $\mathrm{p}<0.001$ & $\mathrm{p}<0.001$ & $\mathrm{p}<0.001$ & $\mathrm{p}<0.001$ & $\mathrm{p}<0.001$ & 1.000 \\
\hline Jun & 1.000 & 1.000 & 1.000 & & $\mathrm{p}<0.001$ & $\mathrm{p}<0.001$ & $\mathrm{p}<0.001$ & $\mathrm{p}<0.001$ & $\mathrm{p}<0.001$ & 1.000 \\
\hline Jul & $\mathrm{p}<0.001$ & $\mathrm{p}<0.001$ & $\mathrm{p}<0.001$ & $\mathrm{p}<0.001$ & & 0.241 & 0.152 & 0.448 & $\mathrm{p}<0.001$ & $\mathrm{p}<0.001$ \\
\hline Aug & $\mathrm{p}<0.001$ & $\mathrm{p}<0.001$ & $\mathrm{p}<0.001$ & $\mathrm{p}<0.001$ & 0.241 & & $\mathrm{p}<0.001$ & 0.005 & $\mathrm{p}<0.001$ & $\mathrm{p}<0.001$ \\
\hline Sep & $\mathrm{p}<0.001$ & $\mathrm{p}<0.001$ & $\mathrm{p}<0.001$ & $\mathrm{p}<0.001$ & 0.152 & $\mathrm{p}<0.001$ & & 0.338 & $\mathrm{p}<0.001$ & $\mathrm{p}<0.001$ \\
\hline Oct & $\mathrm{p}<0.001$ & $\mathrm{p}<0.001$ & $\mathrm{p}<0.001$ & $\mathrm{p}<0.001$ & 0.448 & 0.005 & 0.338 & & $\mathrm{p}<0.001$ & $\mathrm{p}<0.001$ \\
\hline Nov & $\mathrm{p}<0.001$ & $\mathrm{p}<0.001$ & $\mathrm{p}<0.001$ & $\mathrm{p}<0.001$ & $\mathrm{p}<0.001$ & $\mathrm{p}<0.001$ & $\mathrm{p}<0.001$ & $\mathrm{p}<0.001$ & & $\mathrm{p}<0.001$ \\
\hline Dec & 1.000 & 1.000 & 1.000 & 1.000 & $\mathrm{p}<0.001$ & $\mathrm{p}<0.001$ & $\mathrm{p}<0.001$ & $\mathrm{p}<0.001$ & $\mathrm{p}<0.001$ & \\
\hline
\end{tabular}

Note: Significant differences $(p<0.05 / p<0.01 / p<0.001)$.

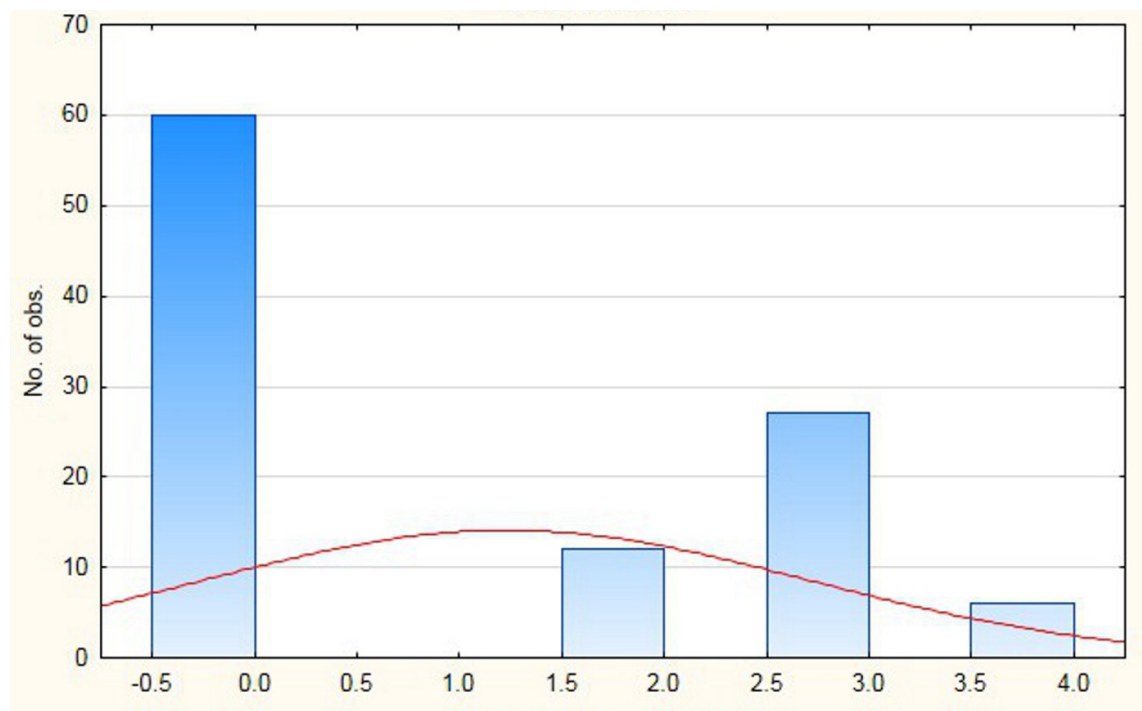

Fig. 4. Amoebas growth curve during 2015-2016 
period (5.0, Tab. 6). Potential differences are significant throughout the year, with bacteria having abundance values according to ecological requirements and availability of food. The months of September-October and January are characterized by a lower abundance of these micro-organisms. The distribution of filamentous bacteria is best outlined throughout the year (Fig. 5). As a microbial group, these bacteria can be a powerful indicator of changing environmental resources, with the normal growth curve being pursued throughout the year.
Rotifers are representatives for the group of microorganisms that live at the edge of ecological niche. They have a fluctuating presence throughout the year. April and June have abundances of up to 1.0, increasing in August-September and November-December respectively (Tab. 7). The maximum is in December (1.25) and is due to the accumulation of biomass needed for the feeding, respectively the achievement of a high potential ecological level. The microbial blades on the edge of the ecological niche have a chaotic development character, appearing and disappearing as activity

Tab. 6. Dynamics of filamentous bacteria in the period 2015-2016

\begin{tabular}{ccccccccccc}
\hline & Jan & Apr & May & Jun & Jul & Aug & Sep & Oct & Nov & Dec \\
\hline Mean & 2.500 & 3.250 & 3.000 & 3.500 & 5.000 & 3.250 & 2.200 & 1.667 & 3.400 & 3.500 \\
\hline Jan & & 0.144 & 0.312 & 0.092 & 0.001 & 0.144 & 0.543 & 0.124 & 0.070 & 0.052 \\
\hline Apr & 0.144 & & 0.528 & 0.625 & 0.009 & 1.000 & 0.009 & 0.001 & 0.705 & 0.549 \\
\hline May & 0.312 & 0.528 & & 0.312 & 0.003 & 0.528 & 0.034 & 0.003 & 0.285 & 0.208 \\
\hline Jun & 0.092 & 0.625 & 0.312 & & 0.040 & 0.625 & 0.010 & 0.001 & 0.839 & 1.000 \\
\hline Jul & 0.001 & 0.009 & 0.003 & 0.040 & & 0.009 & $\mathrm{p}<0.001$ & $\mathrm{p}<0.001$ & 0.015 & 0.025 \\
\hline Aug & 0.144 & 1.000 & 0.528 & 0.625 & 0.009 & & 0.009 & 0.001 & 0.705 & 0.549 \\
\hline Sep & 0.543 & 0.009 & 0.034 & 0.010 & $\mathrm{p}<0.001$ & 0.009 & & 0.217 & 0.002 & 0.001 \\
\hline Oct & 0.124 & 0.001 & 0.003 & 0.001 & $\mathrm{p}<0.001$ & 0.001 & 0.217 & & $\mathrm{p}<0.001$ & $\mathrm{p}<0.001$ \\
\hline Nov & 0.070 & 0.705 & 0.285 & 0.839 & 0.015 & 0.705 & 0.002 & $\mathrm{p}<0.001$ & & 0.800 \\
\hline Dec & 0.052 & 0.549 & 0.208 & 1.000 & 0.025 & 0.549 & 0.001 & $\mathrm{p}<0.001$ & 0.800 & \\
\hline
\end{tabular}

Note: Significant differences $(p<0.05 / p<0.01 / p<0.001)$.

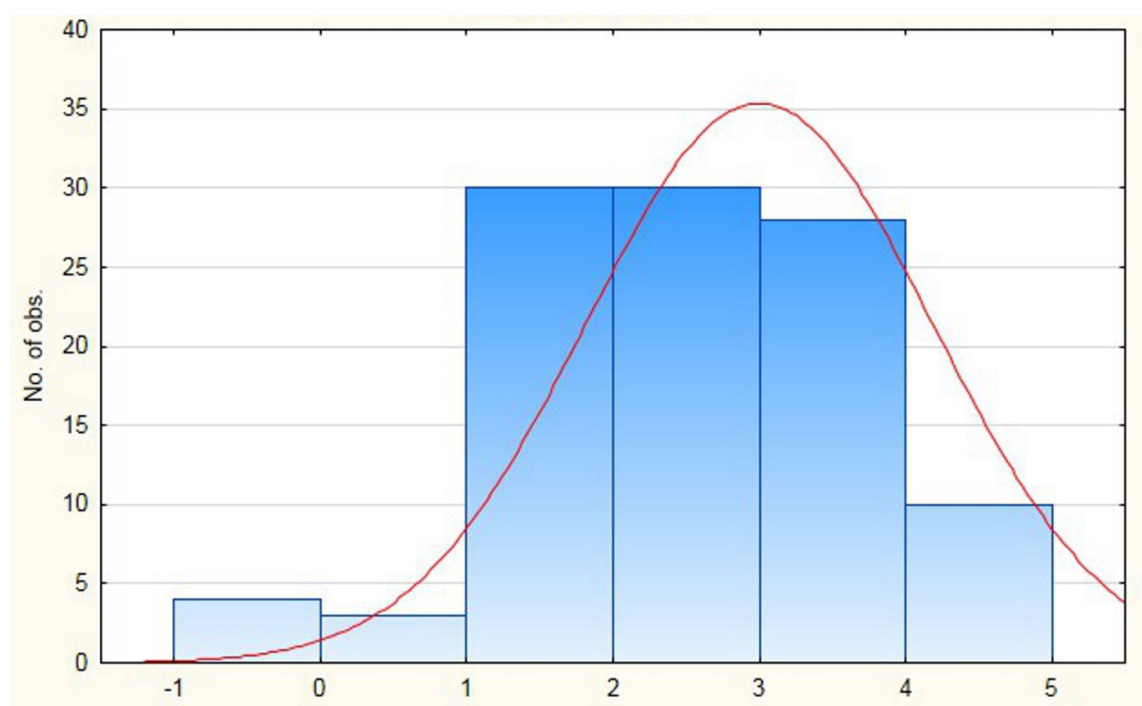

Fig. 5. Filamentous bacteria growth curve during 2015-2016 
in the microbial community (Fig. 6). The use of these microorganisms is high in modeling procedures as they are linked to the dynamics of other microbial groups and respond rapidly to any changes in the environment.

The analysis of the genres and groups present in the sludge is also correlated with the potential to be bioindicators for the qualitative changes of the sludge (Tab. 8). Aspidisca is a colorless genus from fresh waters. It is quite widespread, being found on plants and in detritus of fresh waters and is an indicator of nitrate in the process of treating waste water (Renneberg et al., 2016). Within one milliliter of waste water, up to 25,000 representatives can be found. The prominence of their crests are nitrate indicators, being more prominent at high concentrations. Epistylis are colonial ciliates with a bell-shaped or conical body and a non-contractile stalks, bearing many zoos, being good indicators of biodegradable organic

Tab. 7. Dynamics of microbial groups from the edge of ecological niche in the period 2015-2016

\begin{tabular}{cccccccccccc}
\hline & Jan & Apr & May & Jun & Jul & Aug & Sep & Oct & Nov & Dec \\
\hline Mean & 0.000 & 0.417 & 0.000 & 1.000 & 0.000 & 0.500 & 0.400 & 0.000 & 0.600 & 1.250 \\
\hline Jan & & 0.339 & 1.000 & 0.049 & 1.000 & 0.251 & 0.342 & 1.000 & 0.155 & 0.005 \\
\hline Apr & 0.339 & & 0.218 & 0.181 & 0.458 & 0.814 & 0.961 & 0.278 & 0.586 & 0.021 \\
\hline May & 1.000 & 0.218 & & 0.019 & 1.000 & 0.140 & 0.209 & 1.000 & 0.061 & $\mathrm{p}<0.001$ \\
\hline Jun & 0.049 & 0.181 & 0.019 & & 0.106 & 0.251 & 0.155 & 0.031 & 0.342 & 0.565 \\
\hline Jul & 1.000 & 0.458 & 1.000 & 0.106 & & 0.374 & 0.467 & 1.000 & 0.276 & 0.028 \\
\hline Aug & 0.251 & 0.814 & 0.140 & 0.251 & 0.374 & & 0.766 & 0.194 & 0.766 & 0.037 \\
\hline Sep & 0.342 & 0.961 & 0.209 & 0.155 & 0.467 & 0.766 & & 0.276 & 0.529 & 0.013 \\
\hline Oct & 1.000 & 0.278 & 1.000 & 0.031 & 1.000 & 0.194 & 0.276 & & 0.104 & 0.001 \\
\hline Nov & 0.155 & 0.586 & 0.061 & 0.342 & 0.276 & 0.766 & 0.529 & 0.104 & & 0.056 \\
\hline Dec & 0.005 & 0.021 & $\mathrm{p}<0.001$ & 0.565 & 0.028 & 0.037 & 0.013 & 0.001 & 0.056 & \\
\hline
\end{tabular}

Note: Significant differences $(p<0.05 / p<0.01 / p<0.001)$.

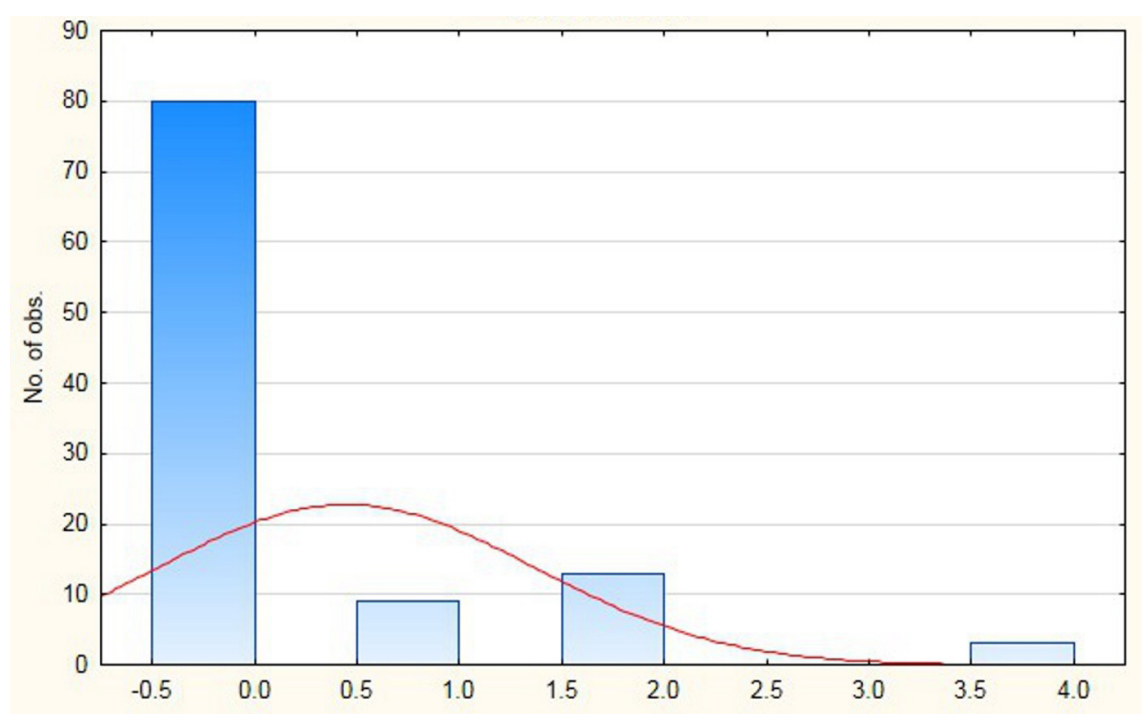

Fig. 6. Growth curve of microbial groups from the edge of ecological niche during 2015-2016 
Tab. 8. Monthly dynamics of genus with bioindicator potential in the period 2015-2016

\begin{tabular}{lcccccccccc}
\hline & \multicolumn{1}{c}{ Number of samples/month } \\
\hline Genus & Jan & Apr & May & Jun & Jul & Aug & Sep & Oct & Nov & Dec \\
\hline Aspidisca & 0 & 9 & 13 & 6 & 0 & 3 & 11 & 8 & 6 & 6 \\
\hline Epistylis & 0 & 0 & 0 & 0 & 0 & 0 & 0 & 0 & 6 & 0 \\
\hline Microthrix & 0 & 0 & 3 & 0 & 0 & 0 & 0 & 0 & 0 & 0 \\
\hline Podophrya & 1 & 2 & 0 & 0 & 0 & 0 & 0 & 0 & 0 & 0 \\
\hline Sphaerotilus & 0 & 3 & 3 & 0 & 0 & 0 & 0 & 0 & 0 & 3 \\
\hline Tokophyra & 0 & 6 & 3 & 0 & 0 & 0 & 0 & 0 & 0 & 0 \\
\hline Votricella & 3 & 6 & 13 & 3 & 0 & 8 & 14 & 8 & 6 & 6 \\
\hline
\end{tabular}

matter (Madoni, 2011). Microthrix are long, thin, non-branched filamentous bacteria, frequently responsible for solid-liquid separation problems in foam and foaming in wastewater treatment plants (Rossetti et al., 2005, Wilson, 2013). Podophrya are protozoa with sticky tentacles identified in industrial effluent treatment plants and are indicators of phenol removal efficiency (Madoni, 2011). Sphaerotilus are aquatic periphitonic microorganisms associated with polluted water, sewage and activated sludge (Chapman, 1996). They can help develop a biofilm that captures suspended particles and stabilizes colonies of other organisms, including Klebsiella and Pseudomonas. It produces technological problems such as clogging pipes and accumulation of active sludge in wastewater treatment. Tokophrya sp. is a carnivorous species of ciliated protozoa, with a role in improving the effluent quality. In their absence, effluents flowing from the system have an increased BOD and are very troubled (Madoni, 1994). Vorticella are solitary species and can be used to clean waste water in waste treatment facilities (Berge and Foissner, 2003).

\section{CONCLUSIONS}

The microbial groups analyzed are influenced both by environmental conditions and by the food competition. The primary role in biological purification is held by bacteria, capable of aerobic and anaerobic processes. In close association with the bacteria in these aerobic treatment processes also intervene protozoa (ciliate and flagelates) and rotifers.

\section{REFERENCES}

1. Agrawal A, Gopal K (2013). Biomonitoring of water and waste water. Springer Science \& Business Media.

2. Camargo JA, Alonso Á (2006). Ecological and toxicological effects of inorganic nitrogen pollution in aquatic ecosystems: a global assessment. Environment international, 32(6):831-849.

3. Chapman DV (1996). Water quality assessments: a guide to the use of biota, sediments and water in environmental monitoring. World Health Organization.

4. Fellman JB, Spencer RG, Raymond PA, Pettit NE, Skrzypek G, Hernes PJ, Grierson PF (2014). Dissolved organic carbon biolability decreases along with its modernization in fluvial networks in an ancient landscape. Ecology 95(9):2622-2632.

5. Findlay S, Sinsabaugh RL (Eds.), (2003). Aquatic ecosystems: interactivity of dissolved organic matter. Academic Press.

6. Grosberg RK, Vermeij GJ, Wainwright PC (2012). Biodiversity in water and on land. Current Biology, 22(21):R900-R903.

7. Howarth W (2005). The progression towards ecological quality standards. Journal of Environmental Law, 18(1):335.

8. Jamieson RC, Gordon RJ, Sharples KE, Stratton GW, Madani A (2002). Movement and persistence of fecal bacteria in agricultural soils and subsurface drainage water: A review. Canadian Biosystems Engineering, 44(1):1-9.

9. Jarvie HP, Jenkins A (2014). Accounting for ecosystem services in water quality standards compliance.

10. Lu Y, Song S, Wang R, Liu Z, Meng J, Sweetman AJ, Wang T (2015). Impacts of soil and water pollution on food safety and health risks in China. Environment international, 77:5-15

11. Madoni P (2011). Protozoa in wastewater treatment processes: a minireview. Italian Journal of Zoology, $78(1): 3-11$

12. Mara D, Horan NJ (Eds.), (2003). Handbook of water and wastewater microbiology. Academic Press. 
13. Morgan NC, Maitland PS (1997). Conservation management of freshwater habitats: lakes, rivers and wetlands (9). Springer Science \& Business Media.

14. Pipkin BW, Trent DD, Hazlett R, Bierman P (2013). Geology and the Environment. Cengage Learning.

15. Renneberg R, Berkling V, Loroch V (2016). Biotechnology for beginners. Academic Press.

16. Rossetti S, Tomei MC, Nielsen PH, Tandoi V (2005). "Microthrix parvicella", a filamentous bacterium causing bulking and foaming in activated sludge systems: a review of current knowledge. FEMS microbiology reviews, 29(1):49-64.

17. Shen L, Xu H, Guo X (2012). Satellite Remote Sensing of Harmful Algal Blooms (HABs) and a Potential Synthesized
Framework. Sensors (Basel, Switzerland), 12(6):77787803, doi: 10.3390/ s120607778.

18. StatSoft Inc (2011). STATISTICA (data analysis software system), version 10. www.statsoft.com.

19. Verhoeven JT, Arheimer B, Yin C, Hefting MM (2006). Regional and global concerns over wetlands and water quality. Trends in ecology \& evolution, 21(2):96-103.

20. Wilson AJ (Ed.) (2013). Foams: physics, chemistry and structure. Springer Science \& Business Media.

21. Wurzel R (2002). Environmental policy-making in Britain, Germany and the European Union: The Europeanisation of air and water pollution control. Manchester University Press. 